\title{
THE VARDAR RIVER AS A BORDER OF SEMIOSPHERE - PARADOX OF SKOPJE REGENERATION
}

\author{
Armina Kapusta \\ Urban Regeneration Laboratory \\ Institute of Urban Geography and Tourism Studies \\ Faculty of Geographical Sciences \\ University of Łódź \\ Kopcińskiego 31, 90-142 Łódź: Poland \\ e-mail: armina.kapusta@geo.uni.lodz.pl
}

\begin{abstract}
As suggested by its etymology, regeneration usually carries positive connotations while its negative aspects tend to be belittled. However, any renewal results in major morphological, physiognomic, functional or social changes, which imply changes in the meanings encoded in space. These transformations are not always welcome and they may lead to public discussions and conflicts. Skopje 2014 is a project within which such controversial transformations have been taking place. The area surrounding the Vardar River and its banks plays a major role here. On the river banks monumental buildings were erected, bridges over the river were modernised and new ones, decorated with monuments, were built for pedestrians. Bridges can be considered a valuable component of any urban infrastructure as they link different parts of a settlement unit (in the case of Skopje - left (northern) bank and the right (southern) bank; Albanian and Macedonian), improve transport, facilitate trade and cultural exchange. In this context, referring to Lotman's semiosphere theory, they may become borders of semiotic space, which acts as a filter that facilitates the penetration of codes and cultural texts. Yet, in multicultural Skopje meanings attached to bridges seem to lead to social inequalities as they glorify what is Macedonian and degrade the Albanian element. To validate this assumption we carried out semiotic analysis of bridges over the Vardar River which were renewed or built within the Skopje 2014 project to identify their role in shaping the semiosphere of the Macedonian capital.
\end{abstract}

\section{Key words}

Skopje 2014 project • bridges over the Vardar River • semiosphere • urban semiotics • ruining and demolishing $\bullet$ multicultural city

\section{Introduction}

Social geography approaches rivers from two angles: as elements that enable human beings to get in touch with each other and to carry out all sorts of exchange or as natural barriers. This dualism is also familiar to urban planners who, following Lynch 
(1960), in the first case would call a river a path, while in the second case an edge. Human activity may transform the functions of watercourses and structures erected to this end (e.g., bridges and their decorative elements) may be used to create new meanings. Barthes (1986) argues that by going beyond functional studies towards studying the meanings encapsulated in urban forms we pave ways to semiotic analyses of cities. Since rivers are often perceived as barriers, reference to the semiosphere theory developed by Yuri Lotman (1984a) within the semiotics of culture seems interesting as when considering semiotic space Lotman paid special attention not only to its centre but also to the borders. By making reference to this concept, the paper attempts to transpose Lotman's idea into the grounds of geography and analyse rivers as semiosphere borders. Studies on urban space, which combine geographic approach (spatial) with cultural and semiotic aspects are scarce, yet they help us learn about social stratification, relationships among analysed groups, and ways of space organisation (Lagopoulos \& BoklundLagopoulou 2014; Kapusta 2015).

Considerations focus on the Vardar River, the axis of Skopje, the capital city of the Republic of North Macedonia, located in a narrow valley. The Vardar River divides the city into two parts, which differ with ethnic, religious, and language composition. The historic, central part of the city, in the northern district by the name of Cair is inhabited mainly by ethnic Albanians (mostly Muslim), while the southern Centar is dominated by Orthodox Macedonians. Although the Vardar River does not act as an administrative border between them, it is seen as the border between cultures which underwent two serious transformations over recent 60 years. The first impulse came from the 1963 earthquake and destroyed ca. $80 \%$ of the city. Another is the effect of the policy pursued in the period 2006-2017 by the then ruling party The Internal Macedonian Revolutionary Organization - Democratic Party for Macedonian National Unity (VMRO-DPMNE), which aimed at reflecting, also in the public space, the Macedonian tradition and legacy and its assumptions are implemented through, inter alia, the Skopje 2014 project announced in 2010. Regeneration is particularly visible in the central part of the city, near the Vardar River. It covers areas adjacent to the river, the riverbed and bridges with rich ornaments that provide them with semantic value. The analysis of meanings attributed to bridges constructed or reconstructed under the Skopje 2014 project is the subject of our considerations focusing on issues, such as the interpretation of river and its infrastructure as a border of the semiosphere, using regeneration to transform the semiotics of space and bridges as instruments of semiotic stigmatisation and exclusion, identifying differences between functionality and semantics of river infrastructure. In order to solve these research questions we discuss Lotman's idea of semiosphere, provide basic data about Skopje and the role of the Vardar River after the city was reconstructed following the 1963 earthquake and the assumptions of the Skopje 2014 project. Next, we carry out semiotic analysis of bridges over the Vardar River based on literature studies and field studies conducted by the author in Skopje in September 2016.

\section{Theoretical foundations: the notion of semiosphere}

Theoreticians in semiotics, researchers interested in signs, started dealing with urban aspects of the subject back in the 1960s (e.g., Barthes 1986; Choay 1986; Fauque 1986). By referencing to the Saussurean tradition and in accordance with the structuralist approach, they would seek systems of signs (codes), that is urbems, the smallest meaningful units (analogous to semes in semiotics). However, a city is a creature that is so complex that linguistic methods have proven insufficient. The turn towards post-structuralism and the rise of the semiotics of culture have opened up new opportunities and expanded the spectrum of city-related contexts and 
issues. The sub-discipline has earned itself a special place in the Tartu-Moscow Semiotic School, which brought together academics from diverse research centres of the former Soviet Union, including graduates of the Lomonosov Moscow State University (e.g., Uspensky, Toporov, Ivanov) and the staff from the University of Tartu in today's Estonia, the alma mater of Yuri Lotman regarded as the school's founder and leader. Exchange of views was stimulated through conferences and less formal summer schools but most of all through the first semiotic journal Sign Systems Studies. The years 1964-1992, when the journal was published under Lotman editorship, are considered the active period of the school.

One of the key notions in the Tartu-Moscow Semiotic School is culture understood as everything, which is not natural but transferred through different codes. To Lotman (1967) culture is non-inherited information, which should be explored and internalized. Artefacts as objects made by humans are not only functional but they are also carriers of culture and meanings that can be decoded as a result of the learning process. Objects, to which we assign meaning are referred to as symbols and the relationship between the form of the sign (the signifier) and its meaning (the signified) is arbitrary (Saussure 1998). Culture is shaped by two types of modelling systems: primary, that is a language and secondary, such as, e.g., religion, art or science. Aspects relating to city and space were considered against this background in two editions of Sign Systems Studies (Trudy po znakovym sistemam 1984, 1986). According to Żyłko (2011) the spectrum of city-related issues can be boiled down to the following five major subjects: the founding myth, name of the city, multiethnicity, city and literature, as well as urban morphology, however, interpreted differently than in urban geography. Semioticians of culture considered the semantic order of cities, relationships between cities and their surrounding world (Lotman in 1984b decided that they can be isomorphic or a city can be seen as an antithesis of its surroundings), location vis-à-vis the surrounding areas (central or peripheral), as well as internal organisation of the city (Toporov 1980; Ivanov 1986).

On top of that, Lotman was interested in the overall order of codes and how they are organised. In analogy to the notion of biosphere introduced in 1926 by Vernadsky, he put forward the idea of semiotic space, which he termed as semiosphere (Lotman 1984a). He argued that such space is both precondition and effect of the development of culture and it is necessary for languages to exist and be operational. The process of meaning-making is feasible only within the semiosphere acting as a unified mechanism. Semiosphere, which to Lotman is an abstract (although to explain it he gives real life examples, such as, e.g., the borders of the Roman Empire, boundaries of an exhibition room), is internally diverse, filled with conflicting structures and semiotic processes that take place in this system are non-synchronised. Its centre is made of a core hosting dominant semantic systems and it is counterbalanced by peripheries. The heterogeneity of the semiosphere is also expressed in the opposition internal vs external. One of typical attributes of semiosphere is its boundary acting as a filter that enables the flow of the individual texts of culture and acts as a link and a dividing border. For that very reason it is also an area within which most of semiotic exchange takes place, where texts of culture can be adapted and moved towards the centre or rejected.

By analysing Lotman's theory we may realise that boundary interpreted in this way is a positive component of semiosphere, as it becomes a reservoir of innovation, accompanied by dynamic processes of semiotic exchange, which facilitate the expansion of semiotic space and codes existing in it. Lotman stressed that the space of semiosphere is an abstract notion and he juxtaposed it with non-semiotic spaces, however, examples that he provided lead to the conclusion that we may also speak of real semiotic spaces. State borders usually delineate boundaries of specific languages, while 
borders of regions identify areas of concrete cultural codes. In this context we may come back to the role of rivers in the development of societies. Surely, rivers are boundaries, barriers that help cultures develop independently on their both banks (e.g., Pest and Buda on the Danube, Zemun and Belgrade on the river mouth Sava-Danube). However, the possibility to overcome these barriers contributes to enhanced trade and cultural exchange between the two banks and alongside the river course, e.g. Vikings in the 9th century sailing up the Seine reached Paris; the Varangians moved alongside the rivers down to the south, from the Baltic to the Caspian Sea on the Volga trade route and through the Dnieper and the Dniester to the Black Sea on the trade route from the Varangians to the Greeks. River cultures can control other influences by blocking river transport. These pragmatic moves are reflected in semiotic processes, control their exchanges by, inter alia, placing symbols around them, which may be followed using the example of the Vardar in Skopje. The bridges, from a semiotic perspective, can be considered as texts and at the same time, sub-texts of the city.

\section{Factors conditioning spatial and social development of Skopje until 1963}

Skopje lies in the heart of the Balkan Peninsula. Natural conditions and historical factors have helped it preserve many attributes typical of the cities of the Balkan interior. We need to discuss them to be able to understand the symbols encoded in the urban space. The history of the city has been prepared based on: Janevski (1970); Čipan (1978); Dojčinoski (1999); Jovanova (2013).

The city developed in a valley of the Vardar River surrounded by the mountains. Geographic location determines the specificity of Skopje, which stretches across ca. $30 \mathrm{~km}$ alongside the west-east axis and is only $10 \mathrm{~km}$ wide. The Skopje valley was inhabited already in the Neolithic. In this early phase it was a settlement of the Dardanians, which in the 4th century BC, together with the adjacent southern territories of Paeonia, was subordinated to Philip II of Macedon. In the 2nd century BC the area was conquered by the Romans who turned it into their military camp. Roman Scupi, which following the Theodosius divide in 395 AD found itself within the borders of the Byzantine Empire, was depopulated after the earthquake in 518 AD. At that time, its inhabitants moved to the left bank of the Vardar. It is believed that the new city of Justiniana Prima was established by emperor Justinian. In 6th century $A D$, the place was reached by Slavic tribes, which started the Slavicisation of the region permanently suffering from wars between the Byzantine Empire and the First Bulgarian Empire (681-1018). The city developed under the rule of tsar Samuel (997-1014), however, following the Battle of Skopje in 1004 AD it returned to the Byzantine Empire. The 11th century witnessed a series of rebels against the Byzantine rule (e.g., Petar Delyan uprising in 1040 or Georgi Voyteh uprising in 1072). Fights were fought also with the Normans and Serbs. However, over the 12th century the city was a thriving settlement and the major development in its history was its subordination to the Serbian ruler Stefan Nemanja in 1189-1190. That was the period of the increasingly more powerful Second Bulgarian Empire (1185-1396) and already in 1204 Skopje came under the rule of tsar Kaloyan and after his death in 1207 under the rule of Serbian vassal Strez. In 13th century Skopje was ruled by: despot of Epirus, tsars of Bulgaria, emperors of Nicaea, king of Serbia Uroš, the Byzantines. In 1282 Skopje was conquered by Stefan Milutin, who made it his capital under the rule of the Serbian Nemanjić dynasty for 110 years. In the 14th century the city flourished as a cultural, religious and economic centre. The culminating point for Skopje in this period came in 1346 with the coronation of Stefan Dušan, the most outstanding ruler in the Balkans in the 14th century, as the Emperor of the Serbs and Greeks.

In the Balkans the 14th century witnessed the rise to power of the Ottoman Empire, which 
conquered Skopje on 6/19 January 1392 under the rule of Bayezid I. The city, whose official name was changed to Üsküp, remained under the Ottoman control for further 520 years and was an important administrative centre of the Sanjak of Üsküp ruled by, inter alia, Pasha Bey (1392-1414), Ishak-Beg (1414-1439), and Isa-Beg Isaković (1454-1463). The subsequent inflows of Turks, Sephardi Jews, as well as Albanians, Greeks, Roma, and Vlachs into the territory marked with clear influences of Dardanian, Hellenic, Roman, Slavic, and Byzantine cultures transformed the social structure of the city. Over the Ottoman period the image of Skopje radically changed. Already in the 15th century, the centre witnessed the replacing of Orthodox churches with mosques, minarets, and türbes. They were followed by clock towers, hammams, hans, madrasas, bedestans, residential districts (mahala), and the reconstruction of the Stone Bridge. At that time, the district presently called Stara Čaršija (Old Bazaar) was the biggest commercial centre of the city. Physical space of the city evolved not only as a result of decisions taken by the new authorities but also due to natural disasters, such as the earthquake of 1555 or the fire in 1594. In 1689 the city was occupied by Austrian army led by general Eneo Silvio Piccolomini, who, wishing to prevent the outburst of the epidemics, ordered to set the city on fire on 25 October 1689. At the same time an anti-Ottoman uprising broke out led by Karposh. These series of events contributed to the drop in the population by ca. $90 \%$ (from 60 thousand in the 17th century to 6 thousand in the early 18th century).

The first half of the 19th century was marked with construction efforts initiated or at least approved by Havzi Pasha and hodja Trajko Dojčin, which resulted in the revival of the city as a centre of trade. In 1873 Skopje was connected by a railway connection with Thessaloniki. The railway station was built south of the Vardar River, which until that time had been the southern border of the city. The development of railway transport initiated the construction of the right bank of the river. Slavs opposed the Hellenisation, speaking Greek in schools and using it in religious functions (for his views and activism Yordan Hadzhikonstantinov was expelled from Skopje in 1857), as well as the Ottoman rule. The Internal Macedonian Revolutionary Organization (IMRO), leading eg. by Goce Delčev, actively inspired the Ilinden Uprising in 1903. Finally, the Turks were ousted from the city in 1912. Skopje found itself within the borders of Serbia, while during World War I, since 1915 it was part of Bulgaria to be incorporated to the Kingdom of Serbs, Croats and Slovenes in 1918. The Balkan wars were times when Turkish population emigrated while Serbs were gradually moving in to the city.

During World War II, the city was occupied first by the Nazi army and then by Bulgarian forces. In March 1943 more than 3 thousand of Jews residing in the city were deported to Treblinka. Finally, Skopje was incorporated into Yugoslavia in 1944. After the WWII the growth of the city was disrupted by natural disasters: flood in 1962 and the earthquake at 05:17 AM on 26 July 1963. The latter inflicted the biggest spatial changes in Skopje in the 20th century. Over one thousand people were killed, more than 3 thousand injured, ca. 150 thousand left homeless and ca. $80 \%$ of buildings were ruined (Fig. 1).

The entire world was helping the inhabitants of Skopje. Among different forms of assistance there were plans of reconstruction drafted for the city. The Master Plan initiated by United Nations was adopted in 1965 and implemented by Polservice, Doxiadis Associates and the Institute for Spatial and Urban Planning of Macedonia. The City Centre Plan was elaborated in 1967 by the team of Kenzo Tange in cooperation with Croatian architects. As the result, modernist buildings were introduced into Skopje landscape including brutalist architecture unusual in Balkan cities. Guidelines developed by the team of experts working under UN auspices with Ciborows$k i$ as one of its members covered also the city centre. It was decided that the Kale hill should not be covered with the nearby buildings but it should be harmoniously combined with the surroundings. The Old Bazaar was 


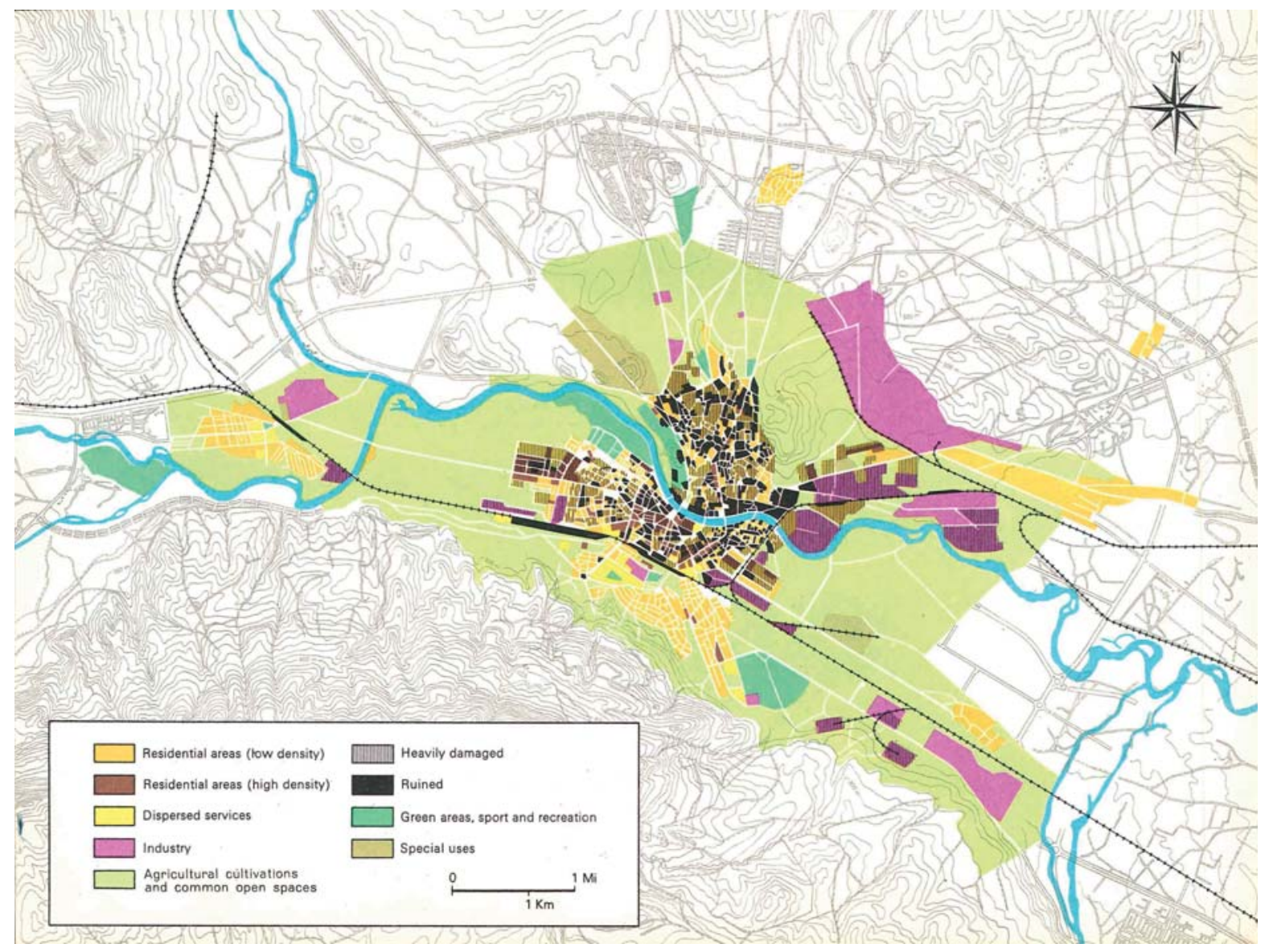

Figure 1. Skopje after the earthquake in 1963

Source: Skopje Resurgent, 1970: 221 
not supposed to be an open-air museum but an integral part of a modern city performing a variety of functions. The Vardar River was also expected to link the northern and southern parts of Skopje. Due to the fact that areas adjacent to the valley of the river are exposed to damage and threatened with earthquakes, it was decided to reduce the density of buildings at river banks (Skopje Resurgent 1970). Reconstruction changed also the social structure as a result of resettlements and rapid inflow of people. According to data from the census in 1961 the city had 197,000 residents; ten years later the population grew to 312 thousand. In 1994, three years after the proclamation of independence of the Republic of Macedonia, Skopje had 448 thousand residents and 506 thousand in 2002. Its central districts: southern Centar and northern Čair are the smallest $\left(7.52 \mathrm{~km}^{2}\right.$ and $3.52 \mathrm{~km}^{2}$, respectively) but densely populated. According to the census of 2002, out of 65 thousand inhabitants of Čair 57\% were Albanians, 24\% Macedonians, 7\% Turks, while 45 thousand residents of Centar included $85 \%$ of Macedonians, $4.5 \%$ of Serbs, $3 \%$ of Albanians and representatives of other nationalities. These districts with their different origin and housing stock (Fig. 2) are dominated by representatives of different nationalities but diversity and multiethnicity is their common feature and the two factors permeate and complement each other. Administrative borders between them delineated north of the Vardar remain invisible to the people and the river acts as a natural border.

The history of Skopje and the whole region is extremely complex. We have brought it to your attention to highlight the most important persons and events that influenced the city's development. Furthermore, over the centuries Skopje was being destroyed by natural disasters as well as due to political transformations; both entailed numerous reconstructions. Each change in power in the city exerted significant impact upon the community of Skopje and provoked migration flows. Subsequent rulers would change the policy vis-à-vis the local people and radically transform urban housing stock and the economy. Over centuries Skopje developed into a multicultural city, which can be seen in its complex social and physical structures. Changes in urban space are currently taking place within the framework of multidimensional Skopje 2014 project, which is not officially referred to as a regeneration project but exhibits many qualities typical of the process.

\section{Bridges on the Vardar River in Skopje 2014 Project}

Back in 2010 the then ruling party VMRO-DPMNE initiated the Skopje 2014 project intended to transform the urban space of Skopje to give it a more monumental character and promote values and contents important for the Macedonians. Until 2017 in total 137 structures were built including baroque and neoclassical buildings, car parks, monuments, squares, a Ferris wheel, bridges, a triumphal arch, fountains, etc. Most of them symbolize a nationalist ideology and were used to construct a positive image of Skopje (Graan 2013). These interventions are not officially referred to as regeneration which can be explained by the fact that they were undertaken in non-degraded areas but in locations not fully developed. That is especially true for areas alongside the banks of the Vardar River, which remained non-developed as a result of decisions taken when the city was reconstructed after the 1963 earthquake. Empty spaces allowed constructing new building structures saving the demolition effort. Besides, the project is not designed to help revive the city's economy as newly erected buildings are, inter alia, administration buildings and museums rather than office buildings or factories. However, in the light of the definition proposed by Kaczmarek (2001), we may identify some features of the project that allow classifying it as a regeneration intervention, such as planned activities that adjust the space to changing needs; in this concrete case we mean the wish of local authorities to improve the city physiognomy and simultaneously promote 


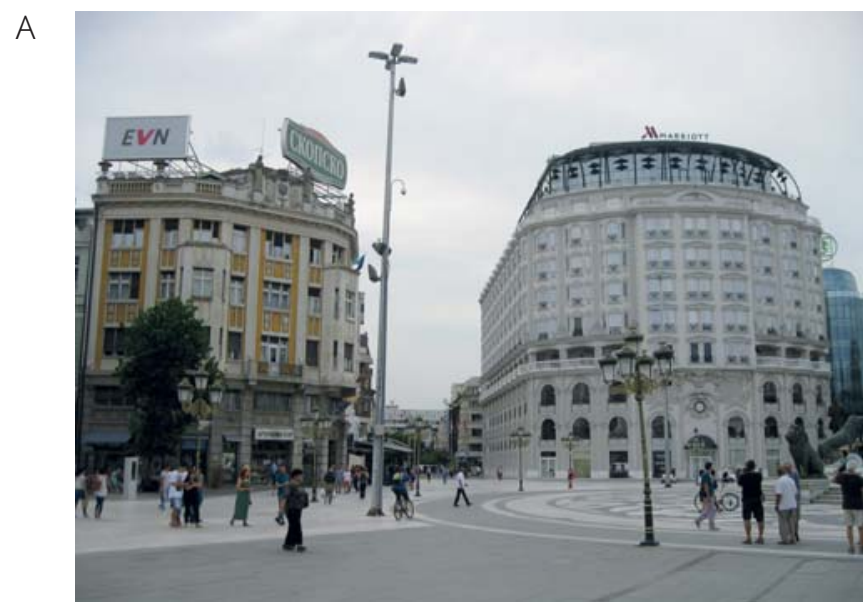

B

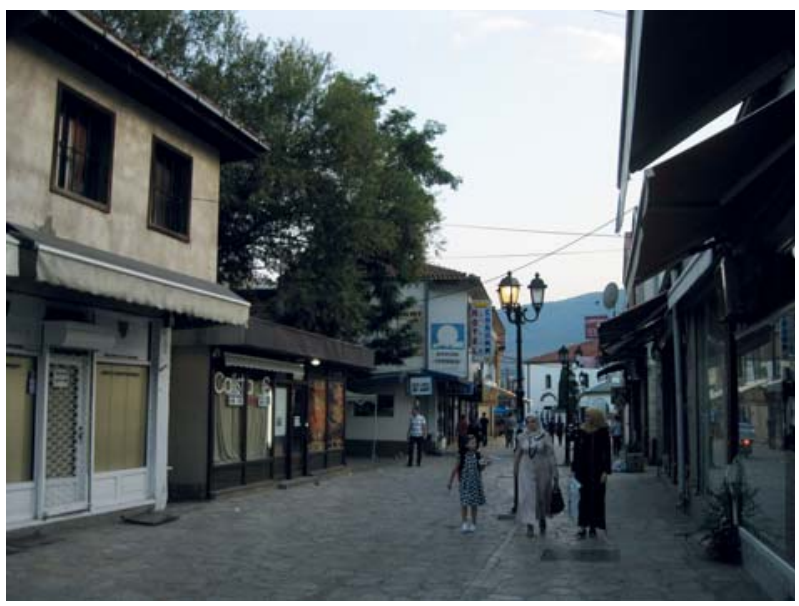

Figure 2. Buildings in Centar (A) and Čair (B) districts (2016)

values and content important for Macedonians. Newly erected buildings transform city morphology and physiognomy. As demonstrated by the studies conducted by the author and discussed below, the project has also transformed social relations. Cultural dimension of the process is obvious and we will examine one of its aspects: the change of semiotics of space. Shaping a new semiotic space of a city consists, inter alia, in commemorating people, who, in the eyes of the decision makers, contributed to the development of Macedonian civilisation and culture, which is why the history of the city is outlined at length in the previous section.
Most of the effort undertaken within the Skopje 2014 project focuses on the Centar district, the most elegant part of the city with the Vardar River as its axis. The project covers not only the banks of the river (e.g., the buildings of the Museum of Archaeology, Agency for Electronic Communications, etc.) but also its bed (ships turned into restaurants, willows, which are monuments symbolising faith, hope, and love, etc.), and bridges. It provided for the renovation of the existing bridges and the construction of new bridges for pedestrians. Bridges are richly ornamented and they are used not just to facilitate traffic but to create new symbols in space. The latter 
will be explained by examining monuments financed under the project and placed on the bridges and along the banks of the Vardar River, which act as an extension of bridges in this function. All the bridges are located in the Centar district with the Stone Bridge in between, which is included in our considerations due to its location (Fig. 3).

In total the analysis covers six bridges, two of them are newly constructed pedestrian bridges (the 'Eye' Bridge and the Art Bridge), three have been renovated (the 'Freedom' Bridge, Goce Delčev Bridge and Mother Teresa Bridge), the Goce Delčev Bridge was also decorated with the sculptures (Tab. 1), while the Stone Bridge has been left unchanged. Considering that, according to the http:// skopje2014.prizma.birn.eu.com/ Web portal [20 October 2018], until January 2018 the Skopje 2014 project delivered 137 undertakings, which consumed ca. EUR 684 m, works connected with the bridges can be regarded as not very spectacular (they represent less than $2 \%$ of the amount spent on the project). However, central location of bridges, their functions and ornaments make them very visible to residents and tourists. By linking the right and left bank of the Vardar River they



Figure 3. Bridges on the Vardar River in Centar district

Source: own compilation based on http:// skopje.gov.mk, 2017. 
Table 1. Bridges on the Vardar River constructed or renovated under the Skopje 2014 project (from west to east)

\begin{tabular}{|c|c|c|c|c|c|c|}
\hline \multirow{2}{*}{ No. } & \multirow{2}{*}{ Bridge } & \multirow{2}{*}{ Built in } & \multirow{2}{*}{ Type of transport } & \multirow{2}{*}{$\begin{array}{c}\text { Works performed } \\
\text { under the Skopje } \\
2014 \text { project }\end{array}$} & \multicolumn{2}{|c|}{ Cost } \\
\hline & & & & & EUR & MKD \\
\hline \multirow[t]{3}{*}{1} & $\begin{array}{l}\text { Goce Delčev } \\
\text { Bridge }\end{array}$ & 1973 & road, pedestrian & $\begin{array}{l}\text { reconstruc- } \\
\text { tion of railings } \\
\text { in } 2011\end{array}$ & 557,967 & $34,314,999$ \\
\hline & & & & $\begin{array}{l}\text { two sculptures } \\
\text { of lions placed } \\
\text { in front of the } \\
\text { bridge on the } \\
\text { right bank }\end{array}$ & $1,311,907$ & $80,682,250$ \\
\hline & & & & $\begin{array}{l}\text { two sculptures } \\
\text { of lions placed } \\
\text { in front of the } \\
\text { bridge on the } \\
\text { left bank }\end{array}$ & $1,273,150$ & $78,298,750$ \\
\hline \multirow[t]{2}{*}{2} & The 'Eye' Bridge & 2013 & pedestrian & construction & $2,750,107$ & $169,131,603$ \\
\hline & & & & sculptures & 648,740 & $39,879,500$ \\
\hline \multirow[t]{2}{*}{3} & The Art Bridge & 2013 & pedestrian & construction & $2,342,194$ & $144,044,960$ \\
\hline & & & & sculptures & 583,521 & $35,886,518$ \\
\hline 4 & $\begin{array}{l}\text { The 'Freedom' } \\
\text { bridge }\end{array}$ & 1936 & road, pedestrian & $\begin{array}{l}\text { new Baroque } \\
\text { railings, lights, } \\
\text { partial restora- } \\
\text { tion }\end{array}$ & $2,163,377$ & $133,047,696$ \\
\hline \multirow[t]{2}{*}{5} & $\begin{array}{l}\text { Mother Teresa } \\
\text { Bridge }\end{array}$ & 1963 & road, pedestrian & $\begin{array}{l}\text { restoration } \\
\text { of the bridge, } \\
\text { new railings and } \\
\text { lights }\end{array}$ & 697,710 & $42,909,169$ \\
\hline & & & & Total & $12,328,673$ & $758,195,445$ \\
\hline
\end{tabular}

Source: own compilation based on field research (2016) and http://skopje2014.prizma.birn.eu.com (accessed December 2017).

perform an important transportation function connecting the southern and northern districts of the city: Centar and Čair. Numerous monuments on the bridges give them symbolic meaning and highlight cultural values important to project originators. This is the case of bridges with monuments and of those where railings were changed.

The construction of the Goce Delčev Bridge (Fig. 4), was completed in 1973. It was a simple architectural structure practically with no decorative details designed to streamline traffic and not distract the attention from the nearby establishments (e.g., the Kale hill). The bridge was named after Goce
Delčev (1872-1903), the leader of the liberation movement and a member of the IMRO, currently an important figure in the history of Macedonia and Bulgaria. Since the reconstruction started in 2011 the bridge has changed rather substantially. New railings have changed its colour to gold strongly contrasting with concrete elements, while vertical and horizontal lines of bridge fence panels have been replaced with more ornamental ones. Vertical elements have been placed on the bridge: three types of richly decorated street lamps. At the entrances to the bridge there are four lions on ornamented pedestals without inscriptions. Lions on the left bank 


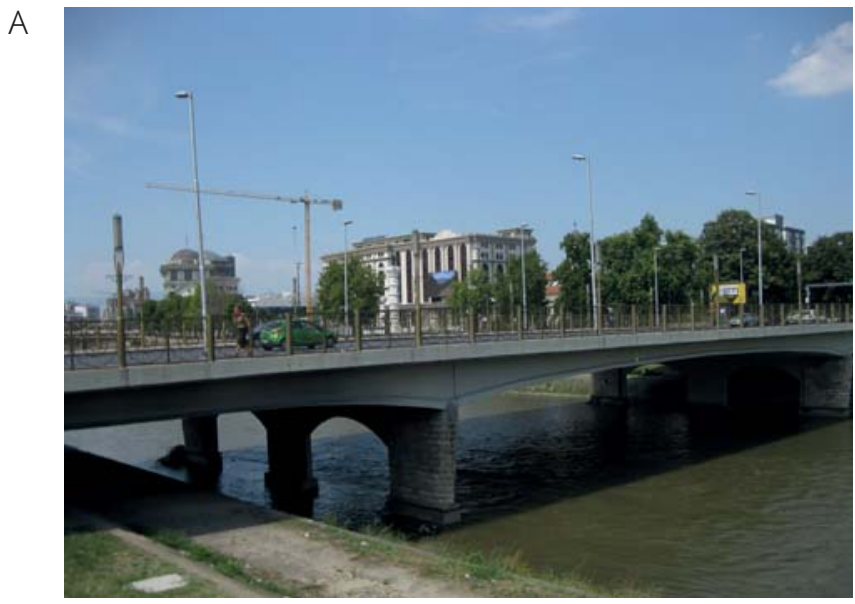

B

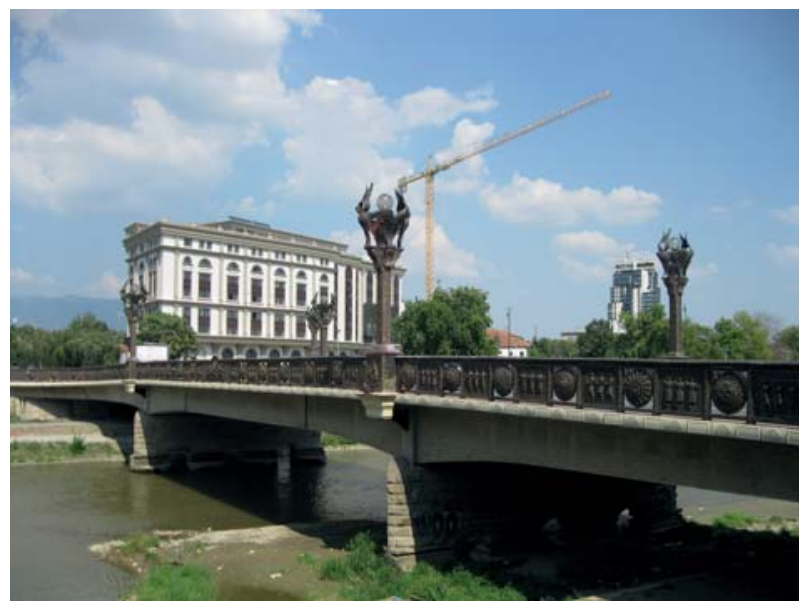

C

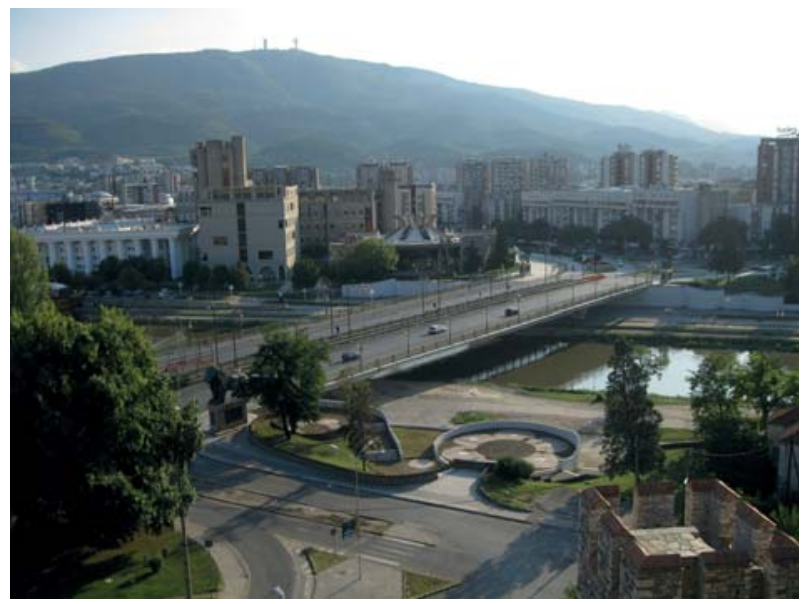

Figure 4. Bridges renovated under the Skopje 2014 project: Mother Teresa Bridge (A), Freedom Bridge (B) and Goce Delčev Bridge (C) 
are geometric forms and ornaments on pedestals make references to the ancient times. Lions on the southern bank of the Vardar River are more realistic and carvings on the pedestals depict events from the two last decades of the 19th century. The authors claim that lions are a Macedonian symbol and they intended to present them as guardians (http://skopje2014.prizma.birn.eu.com/ mk/dva-lava-na-mostot-goce-delchev-desno - accessed on 20 October 2018). The Goce Delčev Bridge has not changed its function but it lost its identity. Its ornaments have sparked a lot of controversy surrounding their cost and the fact that by being a chaotic hybrid they do not provide a coherent narrative and the absence of inscriptions leaves its symbolic aspect unclear.

The Mother Teresa Bridge, previously the Revolution Bridge, was named after the Catholic Church saint born to an ethnic Albanian family in Skopje. The bridge was renovated under the Skopje 2014 project, including the exchange of railings into gold colour ones with fence panels filled with openwork shields. When we were carrying out the field research there were simple street lamps and torch-like outdoor lights as integral parts of the new fencing removed in December 2016.

New railings are also the most characteristic elements of the 'Freedom' bridge (previously Moša Pijade Bridge) constructed in 1936. These railings, similarly to lions on the Goce Delčev Bridge, have drawn harsh criticism from the public due to high costs. The inscription placed on the bridge in Macedonian and English reads: "The Macedonian people fought for centuries for the ideal called freedom. In that struggle, thousands of people lost their lives or were wounded, imprisoned, tortured, exiled and humiliated, but the fight for freedom always continued. This bridge is named in honour of all those generations of people who sacrificed their lives throughout the centuries in the individual and collective fight for freedom".

Although the text explains the name of the bridge, the message of decorations on the railings depicting Macedonian folklore placed alternately with ancient shields remains unclear. There are also 8 characteristic hanging lights with winged silhouettes.

Bridges renovated after 2010 are more functional but their symbols are incoherent, chaotic and not fully understandable; they refer mostly to ancient Macedonia and to the folklore of the Vardar Macedonia. Further two bridges were erected anew and they are used by pedestrians only (Fig. 5). They differ with sculptures that decorate them in a semantically coherent way. On the Art Bridge, we can find sculptures commemorating representatives of the world of culture. The idea behind placing sculptures on the bridge is briefly outlined on open book monuments on both sides of the bridge: in Macedonian on the left-hand page and in English on the right-hand page:

"Built in 2012. The Bridge of Art celebrates the recent Macedonian artistic history. This resplendent bridge is decorated with thirtyfive statues of some of the most significant and distinguished educators, artists, writers, composers and actors from Macedonia, individuals who have had a deep influence on Macedonian art, leaving a treasury of works and cultural wealth that forms an invaluable part of the Macedonian cultural heritage".

The inscription explains whose sculptures these are, however, information is not very precise. Back in 2016 when field studies were conducted the 83 meters long bridge hosted 27 pedestals with 28 statues. There are 13 monuments along each side of the bridge and the statues are facing the central part thereof. In the central part where the bridge becomes wider there are Miladinov brothers facing the south. Monuments can be found also on the left bank of Vardar; eastwards from the bridge there are 3 and westwards 6 sculptures (Tab. 2) with their backs turned to the river. In total, 37 men have been commemorated.

Who are the artists on the monuments we can learn by studying name plaques (sometimes giving also their nicknames), years of birth and death, and main activity area. Information is written in Macedonian and in English; the English version is a latinization 

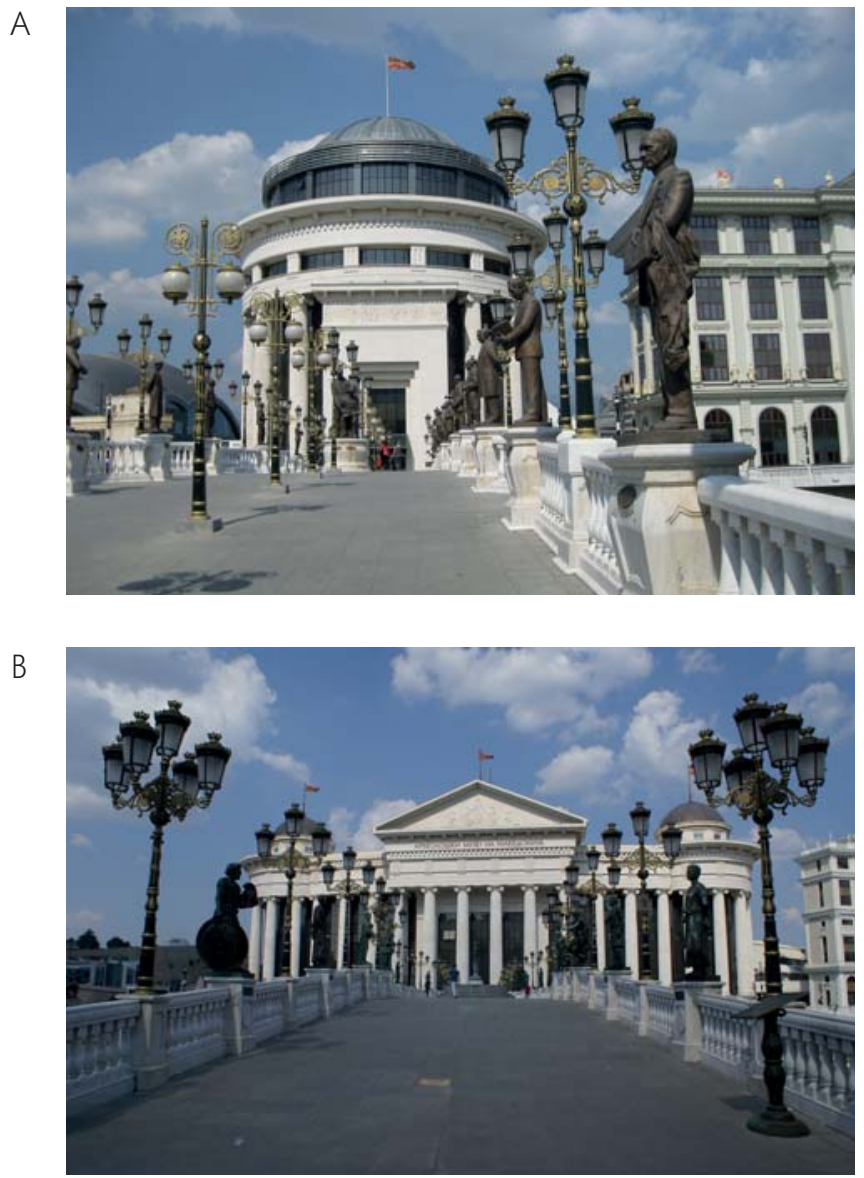

Figure 5. Bridges erected under the Skopje 2014 project: the Art Bridge (A) and the Bridge of Civilisations (B)

of the name written in Cyrillic alphabet. That is rather strange because the same has been done to Turkish and Albanian names, which in the English texts could have been written in accordance with the Turkish or Albanian standard. There is a certain order in the way the statues are placed on the bridge. Its south-east part is occupied by musicians, south-west by painters while the remaining areas of the bridge are occupied mainly by monuments of people linked with literature with the exception of one composer and an actor whose statues are in the north-east part. Monuments on the northern bank of the Vardar commemorate people of different fields of culture. In total there are 8 writers,
7 poets, 5 educators, 5 painters, 4 composers, 2 actors, as well as a singer, grammarian, folklorist, a public person, an author of textbooks and an icon painter who was also a writer. According to information about the bridge, these people should be connected with the modern history of Macedonian art. Sculptures on the bridge depict personalities, whose life and oeuvre cover the 20th century (only 4 come from the 19th century), while 9 monuments on the banks of the Vardar River commemorate people who lived between 17th and 20th centuries. From the inscriptions on the monuments it is hard to learn the nationality, origin or achievements of these people while information about the bridge 
Table 2. Personalities commemorated on the Art Bridge

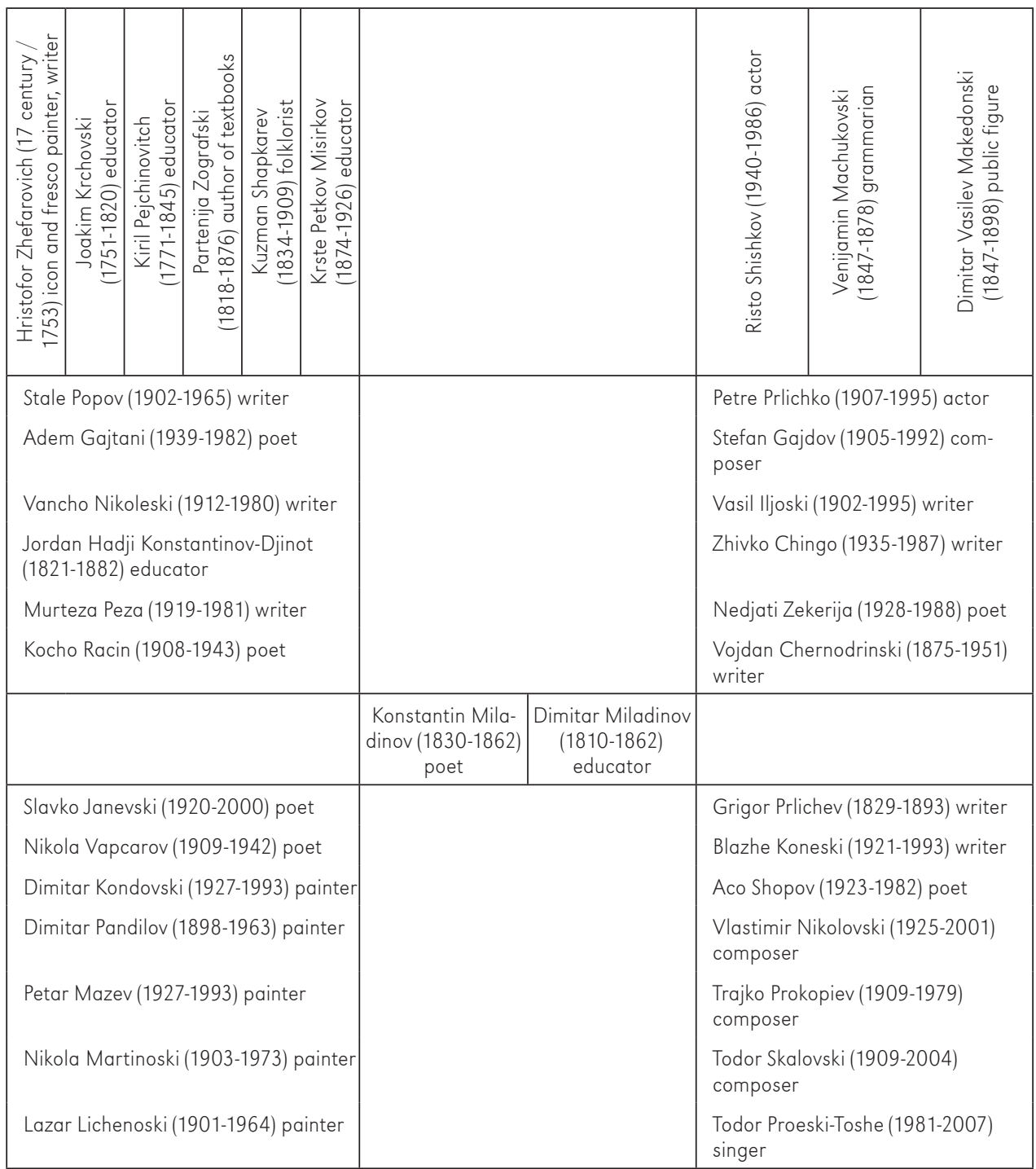

Source: own compilation based on field studies, 2016.

(horizontally - sculptures on the bridge, vertically - monuments on the left bank of the Vardar River; inscriptions on monuments are in Macedonian and English; the Table gives English names only)

suggests that they belong to the Macedonian cultural heritage, exerted powerful impact upon Macedonian art and come from Macedonia. Considering the turbulent history of the region which fuels the still pending dispute between Macedonia, Greece and Bulgaria, such enigmatic and balanced statements should be welcome, however, they encourage further studies. From the latter we have found out that 35 of these people were born in the geographic region of Macedonia, out of them 30 people in Vardar Macedonia and 4 (Vasilev, Machukovski, Shishkov, and Petkov Misirkov) in Aegean Macedonia, while Vapcarov 
in Pirin Macedonia. Moreover, Gajtani was born in Kosovo and Peza in Albania. The fact that the majority of the artists were born in Vardar Macedonia does not mean they were of Macedonian origin. Among commemorated men there is one Turk (Zekerija), two ethnic Albanians (Peza, Gajtani) and Aromanians (Martinoski, Proeski), as well as people considered Macedonians in Macedonia and Bulgarians in Bulgaria (Prlichev, Miladinov brothers, Hadji Konstantinov, Chernodrinski, Vasilev Makedonski, Machukovski, Petkov Misirkov, Shapkarev, Zografski, Pejchinovitch, Krchovski, Zhefarovich, and Vapcarov). The analysis may lead to a paradoxical conclusion that according to the decision makers in Skopje the Ottoman Empire which was the ruling power in the territory for over 500 years favoured the development of Macedonian and Bulgarian culture while Turkish and Albanian influences were marginal. On top of that, we need to note that before Macedonia got incorporated into the Kingdom of Serbs, Croats, and Slovenes, Macedonian - Bulgarian cultural bonds had been very strong and inseparable. Similar complex cultural and historical relations can be observed on the Bridge of Civilisations where, like on the Art Bridge, statues and richly decorated hanging lights were placed. The design idea is explained in the information written on the bridge: "The Bridge of Civilizations in Macedonia was built in 2013. It symbolizes the civilizations that lived and developed on this territory. The statues erected on the bridge represent distinguished individuals from Macedonian and world history. Numerous significant and invaluable archaeological finds dating from the time of their reign have been discovered on the territory of the present-day Republic of North Macedonia. Many of these artifacts which represent the depth of Macedonian history and the spirit of the time when these individuals reigned are displayed in the Archaeological Museum of Macedonia which can be reached via this bridge".

The Bridge of Civilisation is commonly called the Eye Bridge because of its characteristic shape. It leads to the Archaeology Museum and semantically links to it. On both sides of the bridge there are altogether 30 statues, one is in the centre, 8 on the northern bank of Vardar on the east side of the bridge, 4 pedestals with 5 statues on the west (Tab. 3). Nevertheless, contrary to what we can read on the plaque explaining the symbols of the bridge, not only kings (10 people), rulers (4), tsars (3), dukes (2), or provincial governors (1) are commemorated, but also people linked with religious practices: 2 archbishops, 2 archpriests, 3 bishops, 3 hermits, a priestess, metropolitan, church benefactor and manuscript illuminator, a Christian saint, and also a general, a nobleman, 2 rebellion leaders, a scholar, benefactress, a composer, and fresco painters. All these people are connected with the territory and history of Macedonia understood as a geographic region, which, as we can see from the above overview, owes its development mainly to the rulers, to a smaller degree to clergymen and slightly to artists. Sculptures of the latter are placed on the left bank of Vardar, hence we can guess that they semantically connect the Art Bridge and the Bridge of Civilisations. On both information plaques are placed in the same way but on the Bridge of Civilisations these plaques have a different shape and provide different data: name, function, years or century when the person ruled or was active. Apparently, the plaques were made in a hurry and mistakes and omissions impede browsing for detailed information about these people in English language literature. Moreover, searches in Macedonian are also difficult since even if these were 'distinguished individuals' of their times, they were not promoted in historic or popular literature of the 20th and 21st centuries. The remark is true for some of them as many are commonly known and their names have already been mentioned in the section focused on the history of Skopje. To those not very familiar with the history of the region some suggestions may come from the period of activism or the function. Trying to sum up what civilisations "lived and developed on this territory", we need to note that out of the whole commemorated group of personalities 17 lived 
Table 3. Personalities commemorated on the Bridge of Civilisations

\begin{tabular}{|c|c|c|c|c|c|c|c|c|c|c|c|c|}
\hline 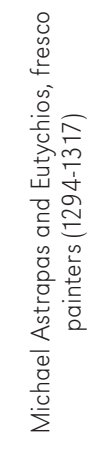 & 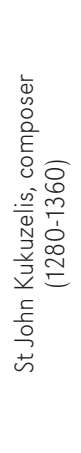 & 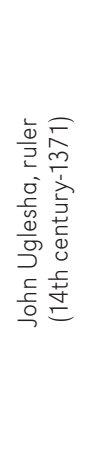 & 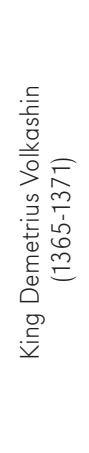 & & 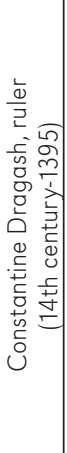 & 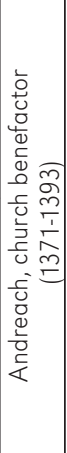 & 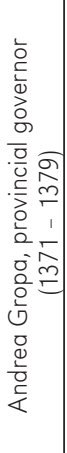 & 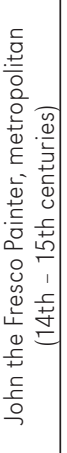 & 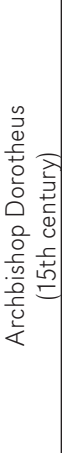 & 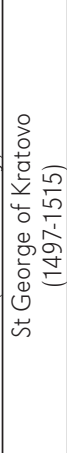 & 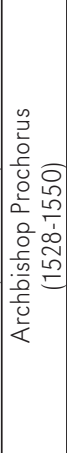 & 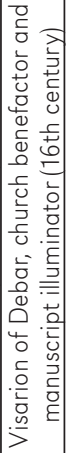 \\
\hline \multicolumn{4}{|c|}{ King Marko (1371-1395) } & & \multicolumn{8}{|c|}{ Tsar Stephen Dushan (1331-1355) } \\
\hline \multicolumn{4}{|c|}{ Dobromir Hrs, ruler (1185-1202) } & & \multicolumn{8}{|c|}{ Sebastokrator Strez, ruler (1207-1214) } \\
\hline \multicolumn{4}{|c|}{ Peter Delyan, rebellion leader (1040-1041) } & & \multicolumn{8}{|c|}{ Georgi Voyteh, rebellion leader (1072-1073) } \\
\hline \multicolumn{4}{|c|}{$\begin{array}{l}\text { St Joachim of Osogovo, hermit (11th-12th } \\
\text { centuries) }\end{array}$} & & \multicolumn{8}{|c|}{$\begin{array}{l}\text { St Prochorus of Pchinja, hermit (11th-12th } \\
\text { centuries) }\end{array}$} \\
\hline \multicolumn{4}{|c|}{ Tsar Ivan Vladislav (1015-1018) } & & \multicolumn{8}{|c|}{ Count Ivats, nobleman (10th -11 th centuries) } \\
\hline \multicolumn{4}{|c|}{$\begin{array}{l}\text { St Gavril of Lesnovo, hermit (11th-12th } \\
\text { centuries) }\end{array}$} & & \multicolumn{8}{|c|}{ Tsar Gavril Radomir (1014-1015) } \\
\hline \multirow{2}{*}{\multicolumn{4}{|c|}{ Duke Hatson (7th century AD) }} & & \multicolumn{8}{|c|}{ Duke Prebond (7th century AD) } \\
\hline & & & & $\begin{array}{l}\text { Paeonian Priestess } \\
\text { (8th-7th centuries) }\end{array}$ & & & & & & & & \\
\hline \multicolumn{4}{|c|}{ Bishop Dionysius (4th century AD) } & & \multicolumn{8}{|c|}{ St Achillius, bishop of Prespa (4th century AD) } \\
\hline \multicolumn{4}{|c|}{$\begin{array}{l}\text { Publius Sentius Septimius Nicholaus, arch- } \\
\text { priest ( } 3 \text { rd century AD) }\end{array}$} & & \multicolumn{8}{|c|}{ Bishop Budius (4th century AD) } \\
\hline \multicolumn{4}{|c|}{ Iulia Tertylla, benefactress ( 2 nd century AD) } & & \multicolumn{8}{|c|}{$\begin{array}{l}\text { Aurelius Crates Ptolemaei, scholar (3rd } \\
\text { century AD) }\end{array}$} \\
\hline \multicolumn{4}{|c|}{ King Perseus (179-168 BC) } & & \multicolumn{8}{|c|}{$\begin{array}{l}\text { Titus Flavius Orestes, archpriest (2nd-3rd } \\
\text { centuries AD) }\end{array}$} \\
\hline \multicolumn{4}{|c|}{ King Audoleon (315-285 BC) } & & \multicolumn{8}{|c|}{ King Philip V (221-179 BC) } \\
\hline \multicolumn{4}{|c|}{ King Amyntas III (392-370 BC) } & & \multicolumn{8}{|c|}{ General Parmenion (4th century BC) } \\
\hline \multicolumn{4}{|c|}{ King Alexander I Philhellene (498-454 BC) } & & \multicolumn{8}{|c|}{ King Archelaus I (413-399 BC) } \\
\hline \multicolumn{4}{|c|}{ King Caranus (9th-8th BC) } & & \multicolumn{8}{|c|}{ King Perdiccas I (707,659 BC) } \\
\hline
\end{tabular}

Source: own compilation based on the field studies, 2016.

(horizontally - sculptures on the bridge, vertically - monuments on the left bank of the Vardar River; inscriptions on the monuments are in Macedonian and English; in the Table we have included only English versions in accordance with the local spelling)

in the ancient times (including 8 in ancient Macedonia, 2 in Paeonia, and 7 in ancient Rome), 21 in the Middle Ages (14 Slavic rulers, one Albanian feudal, 6 monuments were dedicated to people connected with the
Orthodox church), and 5 in the 15th and 16th centuries and all of them were connected with the Orthodox church. Statues on the bridge are placed in chronological order, however, a clear key to their selection is hard to identify, 
except the display of artefacts connected with them in the Archaeological Museum as mentioned on informational plaque. Surely those, whose mammoth monuments already feature in other locations (e.g., Alexander the Great, emperor Justinian) have been omitted. Two personalities connected with Paeonia have been commemorated: king Audoleon and a priestess whose sculpture has been placed in the middle of the bridge with her body facing the east and the head looking up into the skies most probably because the Paeonians worshipped the Sun. The gallery of kings of ancient Macedonia includes the first ruler who integrated Macedonian territories Perdiccas I and Perseus, the last one of the Antigonids dynasty. Important cities of Roman times were, inter alia, Stobi, Heraclea Lyncestis, and Lychnidos (currently Ohrid), and commemorated personalities representing the period between 2 nd and 4th centuries $A D$ were connected with these urban centres with the exception of bishop St Achillius. Thus, it is hard to identify his intentional input into the growth of the Macedonian civilisation. His cult was promoted by tsar Samuel, who wanted to get relics of any early Christian saint and he had St Achillius remains transferred to the island on the Lake Prespa. In the 6th century the Slavs reached these territories, which is why the first dukes Prebond and Hatson have been commemorated together with subsequent rulers, who exerted significant impact upon the Macedonian history but also upon the history of Bulgaria and Serbia. Another commemorated person is Gropa, a Serbian vassal from a noble ethnic Albanian family, administering the region of Ohrid remembered thanks to Serb epic poetry. Poems tell stories also about prince Marko. The Mrnjavčević dynasty, from which he originates is also represented by his father Volkashin, uncle John Uglesha and brother Andreach, referred to as a church benefactor rather than a ruler. Merits for the development of spiritual life were reasons why other people originating from Greece, Bulgaria, Albania, Macedonia, and Serbia have been commemorated. Surprisingly, on the bridge intended to commemorate people who contributed to the growth of Macedonia we can see mainly ancient and Medieval Slavic rulers and representatives of Orthodox Church irrespective of their origin. There is not a single sculpture which would testify to Ottoman influences. They are recalled only by the Stone Bridge (Fig. 6) west of the Bridge of Civilisations and distinctive with its majestic peace. The architecture of the oldest bridge in Skopje is harmonious and plain. It has a characteristic watchtower shaped like a mihrab reconstructed in 2008 with a commemorative plaque in Macedonian and English,

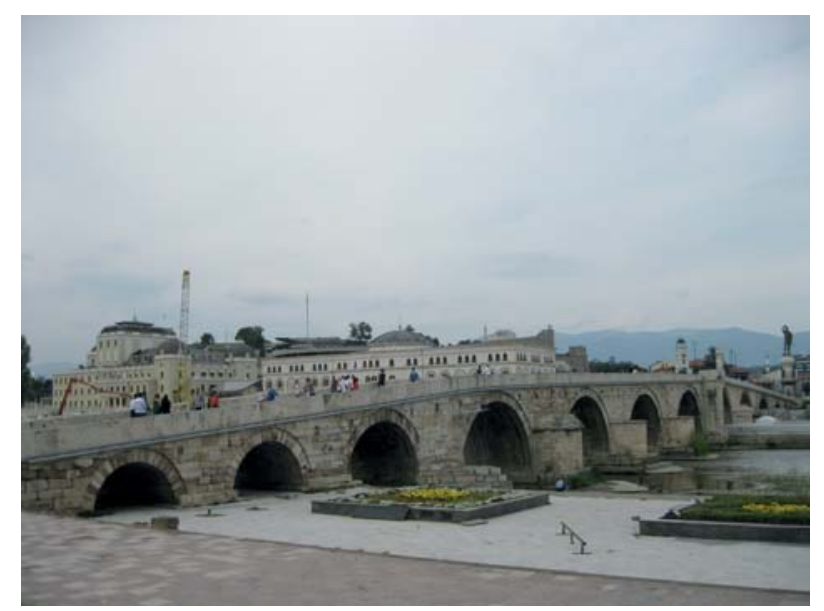

Figure 6. Stone Bridge 
from which we can learn that the bridge was originally built in 1421-1451 during the rule of Mehmed the Conqueror on the foundations from the 6th century. The latest renovation started in 1994 and it went against efforts planned under the Skopje 2014 project. The bridge was restored to its original shape with only two matching plaques: one dedicated to the bridge and the other one commemorating the execution of Karposh. Left without any sculptures, the Stone Bridge is the symbol of the city, link between the northern and southern, Albanian and Macedonian, old and new parts of the city. As one of very few structures in this part of the city that survived the earthquake in 1963, it manifests the spirit and the vitality of the city and its people. Its simple form makes a more powerful semantic statement than pedestrian bridges built in the 21 st century overloaded with decorations.

\section{Conclusion}

Skopje is a city with complex but fascinating history that has been developing for centuries. Natural disasters and conquests entailed morphological, physiognomic, and social transformations. Walking along the streets of Skopje we can study the history of the city and of the region by looking at structures erected under the Skopje 2014 project initiated 19 years after the proclamation of independence of the Republic of Macedonia. Richly decorated bridges over the Vardar River feature prominently among these structures; they also facilitate moving between the oldest district of Čair inhabited mainly by Albanians and located south of it the district of Centar dominated by the Macedonians. These two parts of the city differ significantly between each other not only because they are inhabited by two different nations who speak different languages and have different religious affiliation. Old Bazaar in the Čair district has attributes typical of Turkish cities while the part located south of the Vardar River, which developed mostly after the railway line was put into operation in 1873 and was substantially rebuilt after the earthquake in 1963, combines eclectic and modernist architecture. The Vardar River is a natural border between the two districts, however, in accordance with the 1963 reconstruction plan they were supposed to complement each other with clearly allocated functions and bridges acting as linking elements.

Reconstructions of the existing bridges and the construction of new ones under the Skopje 2014 project could be considered the continuation of this idea, at least in terms of their functionality. However, they were used to promote a specifically interpreted Macedonian heritage. Railings on the bridges are not only utilitarian but they convey some content. Their semantic load, on the one hand, refers to historical periods as well as politicians, artists, and religious personalities important to Macedonian culture. On the other hand, they negate some cultural impacts. Railings and fencing on different bridges present symbols connected with ancient Macedonia and reliefs presenting Macedonian folklore. Besides, the entrance to the Goce Delčev Bridge is guarded by lions (symbols of Macedonia) on pedestals ornamented with reliefs depicting scenes connected with ancient Macedonia and political developments from the late 19th century.

Pedestrian bridges are semantically coherent but difficult to digest as the multiplicity of sculptures featuring on them is overwhelming and tiring rather than encouraging any reflection on Macedonian history and culture. Many statues, in particular on the Bridge of Civilisations, depict people little known to general public and brief inscriptions are not enough to learn about their accomplishments. Literature studies have led us to conclude that commemorated personalities represent ancient Macedonians, inhabitants of the Vardar Macedonia in the Roman times and Slavs (Bulgarians, Serbs and Macedonians). Tribute has been paid to leaders, rulers, people who have contributed to the development of spiritual life, literature, music, and painting. There are few representatives of Albanian and Turkish culture among outstanding 
personalities. In contemporary Macedonia the Ottoman rule which went on for over five hundred years is considered an occupation and symbols placed on the bridges suggest that Turks living in those times and Albanians did not contribute to the development of Macedonian territories neither in political nor in cultural way.

Thus, the Vardar River has turned into a double barrier between the northern and southern part of Skopje: it is not only a natural border but also a border between two cultures posed by symbols placed on it. Bridges could become borders of the semiosphere in the meaning of Lotman, however, in this case they do not act as filters facilitating the exchange of codes but as walls that belong to one semiotic space and are in opposition to the other. We may conclude that this is a lost opportunity to use bridges to improve the communication between two dominant groups in Skopje, build good relations and link districts. Instead, in the city space there is symbolic power in the meaning of Pierre Bourdieu (1991) or structural violence or cultural violence according to Johan Galtung's idea $(1969,1990)$.

On top of that, symbols on the Vardar River are not approved by some Macedonians. Besides those who appreciate their functions and artistic merits, to whom sculptures have become inspirations to dig into the history of the region there are people who believe that costly structures erected under the Skopje 2014 project testify to nationalistic tendencies and erroneous policy of the VMRO-DPMNE government. During the events of April 2016, the so called Colourful Revolution provoked by political scandals in the Republic of Macedonia, people would throw paint of different colours at government buildings and structures constructed under the Skopje 2014 project (including the bridges), which means they are not approved by general public. Establishments built after 2010 regenerate the urban space yet they have also become stigmatising tools.

Bridges covered by the analysis reflect the conflict between transportation function addressed to city dwellers and semantics that highlights values important to Macedonians but paradoxically producing divergent views among themselves. Manipulating symbols results in conflicts and destroys social relations. It is hard to provide an unambiguous assessment of the project and its impact upon residents of Skopje because the interventions have not been completed. At the current stage, if we apply semiotic approach we can conclude that semantically, through the examination of meanings encoded on bridges, the project has produced specific social and cultural regeneration: revival of discussions, bringing back old ideas mostly unknown to residents of contemporary Skopje, and conflict escalation. By the same token, transformations of the urban space lead to the destruction of social bonds between supporters of different ideas of the country development and representatives of ethnic groups inhabiting it: the project favours Macedonians, negates the heritage of the Albanians and excludes Turkish heritage.

Semiotic analysis helps noticing a vital issue in the regeneration of Skopje: the Vardar River which could be a border between the semiospheres with bridges acting as filters becomes a symbolic wall dividing two communities and impeding the building of proper relations between them; it may also become the source of conflicts and disintegration of relations. Yet, the Stone Bridge makes us remember that bridges may and should link, irrespective of the political context, and the Vardar River may be a border of semiotic spaces. After all, river is the best reflection of Heraclitus words panta rhei.

\section{Acknowledgements}

This paper is financed by National Science Centre of Poland based on decision no. DEC2014/15/B/HS4/01940.

Editors' note:

Unless otherwise stated, the sources of tables and figures are the authors', on the basis of their own research. 


\section{References}

Barthes R., 1986. Semiology and the Urban [in:] M. Gottdiener, A.Ph. Lagopoulos (eds.), The city and the sign: An introduction to urban semiotics, New York: Columbia University Press, pp. 87-98.

BOURDIEU P., 1991. Language and symbolic power. Cambridge: Polity Press [translated by Gino Raymond and Matthew Adamson].

ChoAy F., 1986. Urbanism and semiology [in:] M. Gottdiener, A.Ph. Lagopoulos (eds.), The city and the sign: An introduction to urban semiotics, New York: Columbia University Press, pp. 160-175.

ČIPAN B., 1978. Makedonskite gradovi vo XIX vek i nivnata urbana perspektiva. Skopje: Manu.

DoJČINOSKI K., 1999. Skopje - paraleli. Skopje: Matica Makedonska.

FAUQUE R., 1986. For a new semiological approach to the city [in:] M. Gottdiener, A.Ph. Lagopoulos (eds.), The City and the Sign. An Introduction to Urban Semiotics, New York: Columbia University Press, pp. 137-159.

Galtung J., 1969. Violence, peace, and peace research. Journal of Peace Research, vol. 6, no. 3, pp. 167-191.

Galtung J., 1990. Cultural violence. Journal of Peace Research, vol. 27, no. 3, pp. 291-305.

GraAN A., 2013. Counterfeiting the nation?: Skopje 2014 and the politics of nation branding in Macedonia. Cultural Anthropology, vol. 28, no. 1, pp. 161-179.

IVANOV V., 1986. K semiotičeskomu izučeniju kul'turnoj istorii bol'šogo goroda. Trudy po znakovym sistemam, vol. 19, pp. 7-24.

JANEVSKI S. (ed.), 1970. Skopje. Belgrad: Mladost i Sobranie na grad Skopje.

JovanOVA L., 2013. Makedonija vo rimskiot period (arheologija) [in:] P. Kuzman (ed.) Makedonija: mileniumski kulturno-istoriski fakti, Skopje: Media Print, pp. 789-930.

KaCZMAREK S., 2001. Rewitalizacja terenów poprzemysłowych: nowy wymiar w rozwoju miast. Łódź: Wydawnictwo Uniwersytetu Łódzkiego.
KAPUSTA A., 2015. Miejska przestrzeń wielokulturowa Suboticy-analiza geograficzno-semiotyczna. Łódź.

LAgopoulos A., BoKLUnd-LAgopoulou K., 2014. Semiotics, culture and space. Sign Systems Studies, vol. 42, no. 4, pp. 435-486.

LOTMAN Y., 1967. K probleme tipologii kul'tury. Trudy po znakovym sistemam, vol. 3, pp. 30-38.

LotMAN Y., 1984a. O semiosfere. Trudy po znakovym sistemam, vol. 17, pp. 5-23.

LotMan Y., 1984b. Simvolika Peterburga i problemy semiotiki goroda. Trudy po znakovym sistemam, vol. 18, pp. 30-45.

LYNCH K., 1960. The image of the city. Cambridge MA: MIT Press.

Popis na naselenieto, 2002. Skopje: Republika Makedonija, Državen zavod za statistika, http:// www.stat.gov.mk/OblastOpsto.aspx?id=31 [20 December 2018].

SAUSSURE F., 1998. Course in general linguistics. New York: Open Court.

Skopje Resurgent. The Story of a United Nations Special Fund Town Planning Project, 1970. New York: United Nations.

TOPOROV V., 1980. Vilnius, Wilno, Vil'na: gorod i mif [in:] T.M. Sudnik (ed.), Balto-slavianskie etnojazykovye kontakty, Moskva: Izdatiel'stvo "Nauka", pp. 3-71.

Trudy po znakovym sistemam. Semiotika goroda I GORODSKOJ KUL'TURY, 1984. vol. 18, Tartu: Tartuskij gosuniversitet.

TRUDY PO ZnAKOVYM SISTEMAM. SEMIOTIKA PROSTRANSTVA I PROSTRANSTVO SEMIOTIKI, 1986. vol. 19, Tartu: Tartuskij gosuniversitet.

ŻYŁKO B., 2011. Kultura i znaki. Semiotyka stosowana w szkole tartusko-moskiewskiej. Gdańsk: Wydawnictwo Uniwersytetu Gdańskiego.

\section{Website sources:}

http://www.skopje.gov.mk

http://skopje2014.prizma.birn.eu.com 